\title{
Japanese species of Gelanes Horstmann, 1981 (Hymenoptera: Ichneumonidae: Tersilochinae)
}

\author{
Японские виды рода Gelanes Horstmann, 1981 \\ (Hymenoptera: Ichneumonidae: Tersilochinae)
}

\author{
A.I. Khalaim \\ A.И. Халаим \\ Zoological Institute, Russian Academy of Sciences, St. Petersburg, Russia. E-mail: ptera@mail.ru \\ Universidad Autónoma de Tamaulipas, Cd. Victoria, Tamaulipas, Mexico. \\ Зоологический институт РАН, Санкт-Петербург, Россия. E-mail: ptera@mail.ru \\ Автономный университет Тамаулипаса, Сьюдад-Виктория, Тамаулипас, Мексика.
}

KEY WORDS: Japan, South Korea, fauna, new records, key, parasitoids.

КЛЮЧЕВЫЕ СЛОВА: Япония, Южная Корея, фауна, новые находки, определительный ключ, паразитоиды.

ABSTRACT. Five species of the genus Gelanes Horstmann, 1981 are found to occur in Japan: G. clypeatus (Horstmann, 1971), G. cuspidatus Khalaim, 2002, G. gubarevae Khalaim, 2002, G. protritus Kim et Lee, 2013 and $G$. verendus Kim et Lee, 2013. This is the first record of Gelanes from Japan. An identification key to five species occurring in Japan is provided. New data on distribution of Gelanes in South Korea and remarks on type material are given. Colour photographs of G. clypeatus are presented for the first time.

РЕЗЮМЕ. Пять видов рода Gelanes Horstmann, 1981 обнаружены в Японии: G. clypeatus (Horstmann, 1971), G. cuspidatus Khalaim, 2002, G. gubarevae Khalaim, 2002, G. protritus Kim et Lee, 2013 and $G$. verendus Kim et Lee, 2013. Это первая находка рода Gelanes в Японии. Предложен определительный ключ для пяти видов, обитающих в Японии. Представлены новые данные о распространении рода Gelanes в Южной Корее, сделаны замечания о типовом материале. Впервые приведены цветные фотографии G. clypeatus.

\section{Introduction}

The genus Gelanes Horsmann, 1981 was described by Horstmann [1981] for four European species. Khalaim [2002] revised Palaearctic fauna of the genus, described six new species from Carpathians, Middle Asia and South of the Russian Far East, and provided an identfication key to ten Palaearctic species. Later Khalaim [2007] published an identification key to seven species and two variations of Gelanes occurring in the Russian Far East. Based on a large reared material, Khalaim et Blank [2011] described six new species from Europe, provided identification key to 12 European species and ascertained new host records and plant associations for 10 species. Nearctic fauna of the genus was partly revised by Horstmann [2013] who descrided 13 species from USA and Canada. Fauna of South Korea comprising eight species (including four new species) was revised by Kim et al. [2013], and two species, G. cuspidatus Khalaim, 2002 and G. provectus Balueva et Khalaim, 2013, were recently reported from China [Khalaim, Sheng, 2015].

Thus, twelve species of Gelanes are currently known from East Palaearctic region: eight occur in South Korea, two in Palaearctic part of China and eight in Russian Far East, but nothing was known hitherto about distribution of this genus in Japan. The aim of this study is to review Japanese species of Gelanes and provide an identification key to species. New data on distribution in South Korea and remarks on type material of some species described from South Korea also will be provided.

\section{Material and Methods}

Tersilochinae material from the National Institute for Agro-Environmental Sciences, Tsukuba, Japan (further NIAES) has been examined. From this material, twenty specimens belonging to the genus Gelanes were found. Twelve small males (all from Aichi Pref. in Chûbu region) were not identified, and one male was preliminarily identified as G. provectus/cuspidatus. Additional material of Gelanes from the Yeungnam University, Gyeongsan, South Korea (further YNU) was examined. Some specimens are deposited in the Zoological Institute RAS, St. Petersburg, Russia (further ZISP).

Colour photographs were taken in ZISP with a DFC 290 digital camera attached to a Leica MZ16 stereomicroscope. Images were assembled with Helicon Focus software. 
Results

Subfamily Tersilochinae

Genus Gelanes Horstmann, 1981

Type species: Thersilochus fusculus Holmgren, 1860.

Gelanes clypeatus (Horstmann, 1971)

Figs 1-6.

MATERIAL EXAMINED. Japan: Hokkaido Pref., Katō Distr.,

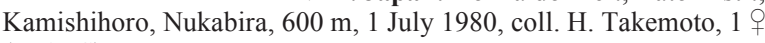
(NIAES).

REMARKS. Antennal flagellum with 22 flagellomeres; flagellomeres 3 to 8 bearing finger-shaped structures at apex of outer surface (strong on flagellomeres 3 to 6 and weak on flagellomeres 7 and 8) (Fig. 1). Lower 0.7-0.8 of clypeus flat, separated by transverse crease from upper $0.2-0.3$ of clypeus (similar to that in G. cuspidatus and G. provectus). Foveate groove on mesopleuron virtually absent, discernible as slightly uneven area. Temple and mesopleuron smooth and shining, with fine and distinct punctures. Basal area of propodeum narrow, indistinct (Fig. 3). Legs brownish yellow, mid and hind coxae slightly darkened with brown. Metasoma behind first tergite brownish black.
DISTRIBUTION. Transpalaearctic species: Europe, Russian Far East (Khabarovsk Terr.), Japan (Hokkaido I.).

BIOLOGY. Host unknown.

Gelanes cuspidatus Khalaim, 2002 Figs 9-10, 14.

MATERIAL EXAMINED. Japan: Miyazaki Pref., Kirishima, Mt. Takachihonomine, 1574 m, 21 May 1982, coll. K. Konishi, 1 ㅇ (NIAES).

REMARKS. Female from Japan is small, with body length $2.9 \mathrm{~mm}$, fore wing length $2.5 \mathrm{~mm}$ and foveate groove rather weak (Fig. 9).

DISTRIBUTION. Transpalaearctic species: Europe, Russian Far East (Khabarovsk and Primorsky Terr.), South Korea, Japan (Kyushu I.), China (Liaoning).

BIOLOGY. Reared from Xyela alpigena (Strobl) (Xyelidae) on Pinus cembra L. (Pinaceae) in Austria [Khalaim, Blank 2011].

Gelanes gubarevae Khalaim, 2002

Figs 11, 15.

MATERIAL EXAMINED. Japan: Miyazaki Pref., Kirishima, Mt. Takachihonomine, 1574 m, 21 May 1982, coll. K. Konishi, 2 우 (NIAES). South Korea: GB, Gyeongsan-si, Daehak-ro 280, Yeung-

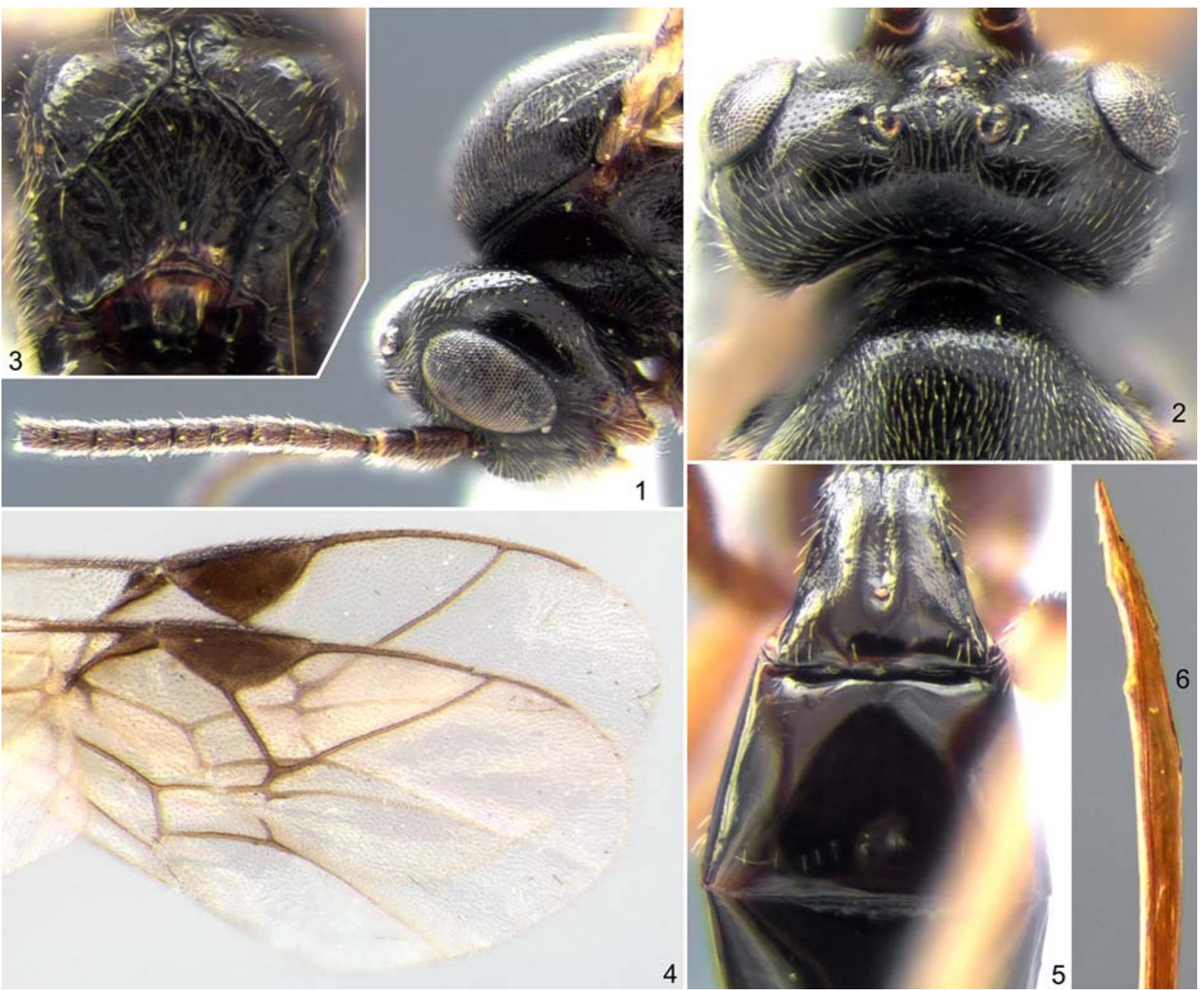

Figs 1-6. Gelanes clypeatus, female (Japan): 1 - head and base of antenna, lateral view; 2 - head, dorsal view; 3 - propodeum, dorsoposterior view; 4 - fore wings; 5 - postpetiole and second tergite, dorsal view; 6 - apex of ovipositor, lateral view.

Рис. 1-6. Gelanes clypeatus, самка (Япония): 1 — голова и основание антенны, сбоку; 2 — голова, сверху; 3 — проподеум, сверхусзади; 4 - передние крылья; 5 - раструб и второй тергит, сверху; 6 - вершина яйцеклада, сбоку. 
nam University, YP, 1 May 2013, coll. K.B. Kim, 1 (ZISP). GB, Cheongdo-gun, Unmun-myeon, Mt. Unmun, N 35 38 $09^{\prime \prime}$,

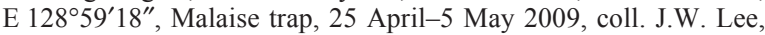
1 ( (ZISP).

DISTRIBUTION. Trans-Palaearctic species: Europe, South Korea, Japan (Kyushu I.).

BIOLOGY. Reared from Xyela graeca Stein and probably $X$. curva Benson on Pinus nigra Aiton (Pinaceae) in Austria; collected from staminate cones of $P$. nigra with Xyela larvae in Greece [Khalaim, Blank, 2011].

Gelanes protritus Kim et Lee, 2013 Figs 7, 12, 16.

MATERIAL EXAMINED. Japan: Chūbu Region, Aichi Pref., Mt. Sanage, evergreen forest, 7-13 May 1993, coll. K. Kato, 1 (NIAES). South Korea: GG, Namyangju-si, Korea Univ. Forestry Experiment Station, 20 May 1986, coll. J.W. Lee, 1 q (ZISP). GW, Donghae-si, Samhwa-dong, Mureung valley, Malaise trap, 21-30 May 2005, coll. J.W. Lee, o ?holotype (YNU) [see Remarks section below].

REMARKS. Original description of this species [Kim et al., 2013: 424] was written by A.I. Khalaim based on the female with label in Korean, collected in 21-30 May 2005. Later the holotype specimen was unexpectedly changed by the first author who also changed its label data in the manuscript but left intact my description. Thus, original description of this species does not completely correspond (especially measurements) to the formal holotype deposited at YNU.

One more problem with the holotype specimen was found. Label data of the holotype female in the YNU collection differs from those cited in the original description [E.N. Balueva, pers. comm.]. Correct label data of the holotype are given in the Material examined section above.

DISTRIBUTION. South Korea, Japan (central Honshu I.).

BIOLOGY. Host unknown.

Gelanes provectus Balueva et Lee, 2013

MATERIAL EXAMINED. South Korea: GG, Mt.Youngmunsan, Yeonsu, Yongmun, Yangpyeong, N 37 $31^{\prime} 49.5^{\prime \prime}$,

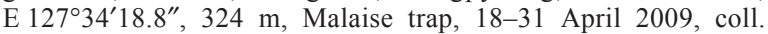
Jongok Lim, $1 \mathrm{O}^{7}$ (ZISP). GN, Sancheong-gun, Samjang-myeon, Yu

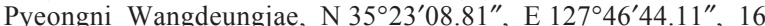
June-20 September 2008, 1 (ZISP). GW, Donghae-si, Samhwadong, Mureung valley, N $37^{\circ} 27^{\prime} 52^{\prime \prime}$, E $129^{\circ} 01^{\prime} 26^{\prime \prime \prime}$, Malaise trap, 29 April - 26 May 2007, 1 ㅇ (ZISP). JB, Namwon-si, Sannae-

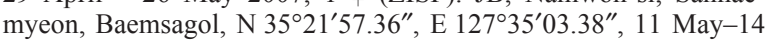
July 2008, 1 ㅇ (ZISP). JB, Jeongeup-si, Bokheung-myeon, Songgotbawi, Malaise trap, 19 May 2004, coll. K.B. Kim, 1 (ZISP). JN,
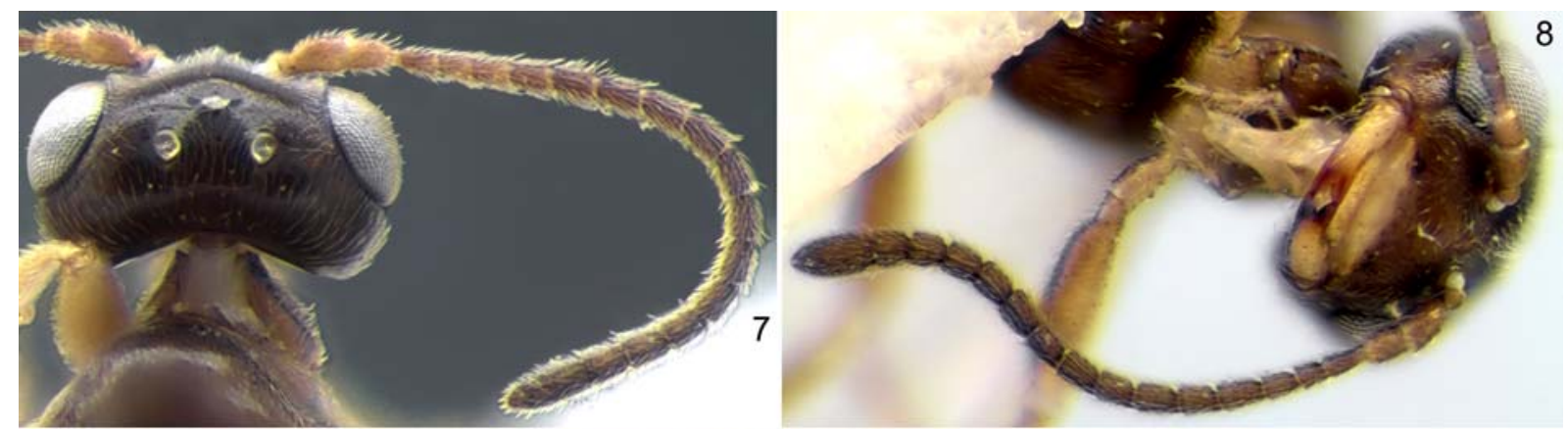
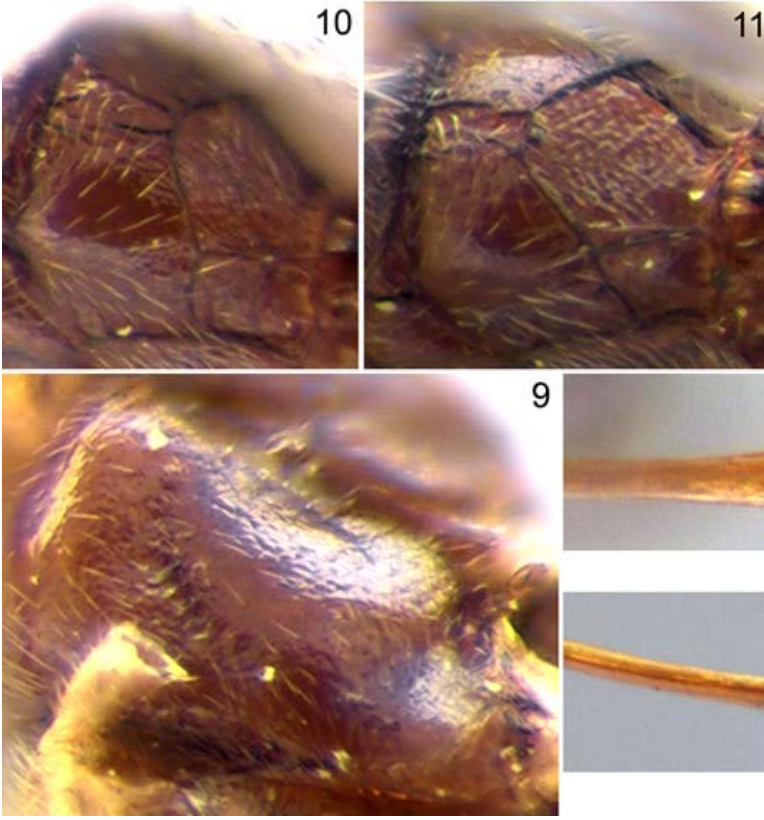

9

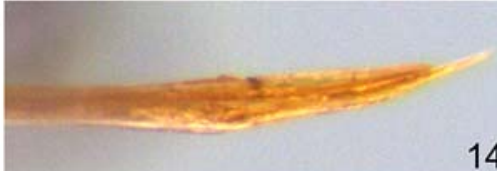

14
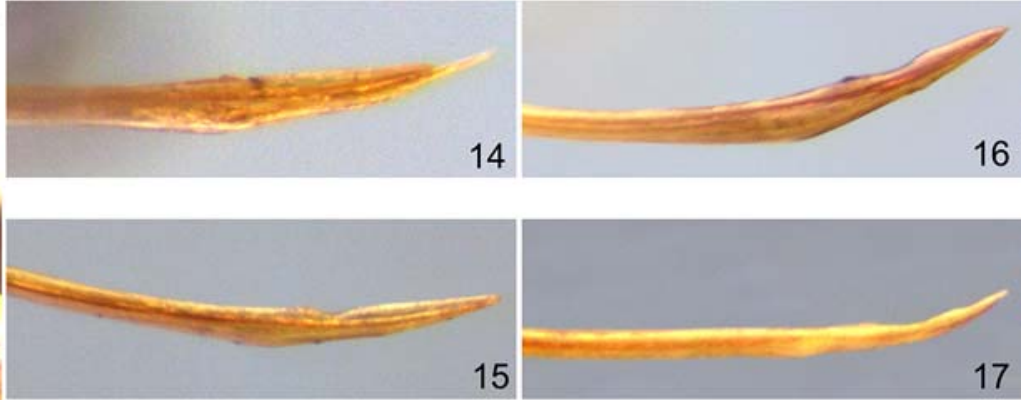

Figs 7-17. Gelanes spp., females (Japan): 7, 12, $16-$ G. protritus; 8, 13, $17-$ G. verendus; 9-10, $14-$ G. cuspidatus; $11,15-$ G. gubarevae; 7-8 - head with antenna, dorsal; 9 - mesopleuron, antero-lateral; $10-13$ - propodeum, dorso-lateral; $14-17$ - apex of ovipositor, lateral.

Рис. 7-17. Gelanes spp., самки (Япония): 7, 12, 16 - G. protritus; 8, 13, 17 - G. verendus; 9-10, 14 - G. cuspidatus; 11, 15 G. gubarevae; 7-8 - голова с антенной, сверху; 9 - мезоплевра, спереди-сбоку; 10-13 — проподеум, сверху-сбоку; 14-17 вершина яйцеклада, сбоку. 
Jeongeup-si, Jangseong-gun, Bukha-myeon namchanggol, Malaise trap, 19 May 2005, coll. D.K. Jung, 1 क (ZISP).

\section{Gelanes simillimus Horstmann, 1981}

MATERIAL EXAMINED. South Korea: GB, Cheongdo-gun, Unmun-myeon, Sariamjuchajang, Malaise trap, 23 March - 12 May 2013, coll. J.W. Lee, 1 क (ZISP). GG, Yangpyeon-gun, Yongmunmyeon, Yeong-ri, Mt. Younmun, 1-26 May 2009, coll. J.W. Lee, 1

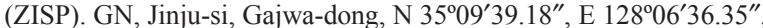
21-28 April 1987, coll. J.W. Lee, 2 of (ZISP). GW, Wonju-si, Heungeop-myeon, Yeonse Univ. Wonju Campus, N 37 $16^{\prime} 24^{\prime \prime}$, E $127^{\circ} 54^{\prime} 02^{\prime \prime}$, Malaise trap, 4-24 May 2007, 2 우 (ZISP)

\section{Gelanes verendus Kim et Lee, 2013} Figs 8, 13, 17.

MATERIAL EXAMINED. Japan: Chūbu region, Aichi Pref., Mt. Sanage, deciduous forest, 30 April - 6 May 1993, coll. K. Kato, 2 우 (NIAES). South Korea: GB, Cheongdo-gun, Unmun-myeon, Mt. Unmun, N 35 $38^{\prime} 19^{\prime \prime}$, E $128^{\circ} 57^{\prime} 40^{\prime \prime}$, Malaise trap, 26 April - 10 May 2009, coll. J.W. Lee, 1 (ZISP). GG, Mt. Youngmunsan, Yeonsu,

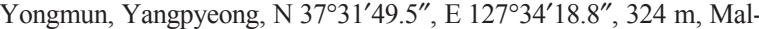
aise trap, 18-31 April 2009, coll. Jongok Lim, 1 (ZISP) [originally marked as holotype, see Remarks section below]. GW, Heugeopmyeon, Maeji-ri, Yeonsedae gyonae ungdeongi, N 37 $16^{\prime} 53^{\prime \prime}$, E 1275'02", 6-28 June 2011, coll. J.W. Lee, 1 ㅇ (YNU).

REMARKS. Original description of this species [Kim et al., 2013: 428] was written by A.I. Khalaim based on the female from GG, collected in 18-31 April 2009. Later the holotype specimen was unexpectedly changed by the first author who also changed its label data in the manuscript but left intact my description. Thus, original description of this species does not completely correspond (especially measurements) to the formal holotype deposited at YNU. Female originally marked as holotype is currently deposited at ZISP (see Material examined section above).

DISTRIBUTION. South Korea, Japan (central Honshu I.). BIOLOGY. Host unknown.

Key to SPECIES OF GELANES OCCURRING IN JAPAN (FEMALES)

1. Head, in dorsal view, with temple almost as long as eye width (Fig. 2). Antenna with 22 flagellomeres. Ovipositor with two dorsal subapical teeth (Fig. 6), its sheath about twice as long as first tergite

\section{G. clypeatus (Horstmann)}

- Head, in dorsal view, with temple shorter, 0.7-0.8 times as long as eye width (Fig. 7). Antenna with 14-18 flagellomeres. Ovipositor sometimes not as above, its sheath 2.4-4.6 times as long as first tergite ............... 2

2. Foveate groove of mesopleuron narrow and sharp, with distinct transverse wrinkles, usually about half as long as mesopleuron length (Fig. 9). Ovipositor at apex lanceolate, with small dorsal notch (Fig. 14)....

2. G. cuspidatus Khalaim

- Foveate groove of mesopleuron weak and short. Ovipositor without dorsal subapical notch
3. Propodeum with short basal keel (Fig. 12) or rarely with very narrow basal area. Ovipositor robust, with apex rather thick and with two dorsal subapical teeth (Fig. 16). 4. G. protritus Kim et Lee

- Propodeum with basal area (Figs 11, 13) which is sometimes indistinct. Ovipositor slenderer, with weak dorsal subapical depression, without dorsal teeth (Figs 15, 17) .............. 4

4. Upper tooth of mandible longer than the lower tooth. Flagellum filiform, subapical flagellomere elongate. Ovipositor evenly upcurved, with dorsal subapical depression far from apex, distance from depression to apex of ovipositor subequal to 4.0 times average height of ovipositor (Fig. 15) ...................... 3. G. gubarevae Khalaim - Upper tooth of mandible as long as lower tooth (Fig. 8). Flagellum distinctly clavate, subapical flagellomere square or slightly transverse (Fig. 8). Ovipositor usually straight in basal 0.9 , with apex conspicuously stronger upcurved, with dorsal subapical depression closer to apex (Fig. 17) 5. G. verendus Kim et Lee

ACKNOWLEDGEMENTS. I am thankful to E.N. Balueva (YNU) for her help with interpretation of Korean label data and important remarks on type material. This work was supported by the Russian Foundation for Basic Research (project no. 16-04-00197).

\section{References}

Horstmann K. 1981. Revision der europäischen Tersilochinen II (Hymenoptera, Ichneumonidae) // Spixiana. Suppl.4(1980). P.176

Horstmann K. 2013. Revisions of Nearctic Tersilochinae V. Genera Allophroides Horstmann and Gelanes Horstmann (partim) (Hymenoptra, Ichneumonidae) // Spixiana. Vol.36. No.2. P.227-261.

Khalaim A.I. 2002. [A review of the species of the genus Gelanes (Hymenoptera, Ichneumonidae, Tersilochinae) of the Palaearctic region] // Vestnik Zoologii. Vol.36. No.6. P.3-12 [in Russian].

Khalaim A.I. 2007. 17. [Subfamily Tersilochinae] // Lelej A.S. (ed.). Keys to the insects of the Russian Far East, Vol.4. Neuropteroidea, Mecoptera, Hymenoptera. Part 5. Vladivostok: Dalnauka. P.566-597 [in Russian].

Khalaim A.I., Blank S.M. 2011. Review of the European species of the genus Gelanes Horstmann (Hymenoptera: Ichneumonidae: Tersilochinae), parasitoids of xyelid sawflies (Hymenoptera: Xyelidae)// Proceedings of the Zoological Institute RAS. Vol.315. No.2. P.154-166.

Khalaim A.I., Sheng M.-L. 2015. Contribution to the study of Chinese Tersilochinae (Hymenoptera: Ichneumonidae) // Zootaxa. Vol.4013. No.2. P.280-286. doi:10.11646/zootaxa.4013.2.8

Kim K.-B., Balueva E.N., Khalaim A.I., Lee J.-W. 2013. The genus Gelanes Horstmann (Hymenoptera: Ichneumonidae: Tersilochinae) from South Korea, with description of four new species // Zootaxa. Vol.3716. No.3. P.417-430. doi:10.11646/zootaxa.3716.3.5. 